\title{
MOETEN PROEFSTATIONS STAATSINRICHTINGEN ZIJN?
}

De boven gestelde vraag is een vraag van beginselen. Landbouwproefstations zijn hulpmiddelen eener bepaalde nijverheid, van den Landbouw. Met het instellen van bureaux ran onderzoek op ander gebied is hetzelfde het geval, on zelfs van de in den laatsten tijd tot stand gekomen laboratoria van den gezondheidsdienst zou men, met het oog op hunne voornaamste werkzaamheden, hetzelfde kunnen beweren.

De gevolgtrekking schijnt dus voor de hand te liggen, dat het tot stand brengen van dergelijke inrichtingen aan den ondernemingsgeest van private personen kon overgelaten blijven, op grond dat, wanneer zij uit zich zelve geen winstgevende ondernemingen kunnen zijn, er ook geen ware behoefte naar haar aanwezig is. Om dit juist met een voorbeeld uit het gebied van landbouw-onderzoek te verduidelijken: zijn de voordeelen, die voor den landbouwer voort kunnen spruiten uit eene analyse van Peru-guano, die vervalscht of op eene of andere wijze minder bruikbaar zijn kan, niet even groot of grooter dan de kosten van deze analyse, dan is het weinig economisch, om door kunstmatige goedkoopheid de zaak te dwingen, en zijn de genoemde voordeelen grooter, welnu dan zal de vindingsgeest der menigte reeds de goede vooruitzichten van eene betrekking als scheikundige ten dienste van 't publiek opsporen, en de noodige inrichtingen zullen van zelve ontstaan.

Zoo ongeveer zou de redeneering kumnen zijn van die oudere, (thans minder absoluut sprekende) staathuishoudkunde welke de voorziening in alle economische behoeften aan de eenvoudige werking van het laissez-fuire beginsel meende te kunnen overlaten, on daarop geene of nagenoeg geene uitzondering wilde toelaten.

De praktische ervaring wil echter niet volkomen stemmen met die oogenschijnlijk zeer plausiebele theorie, die door haar eenvoud zeer geschikt was, om onder de groote menigte aanhangers te verwerven. Bepaaldelijk de wijze, waarop zich het "landbouw-onderzoeksECON. 1884. 
wezen", sit venia verbo, in de laatste 30 jaren in de meeste beschaafde landen van Europa en tegenwoordig ook van NoordAmerika uitgebreid heeft, logenstraft de eenmaal geliefde stelling. Deze zou meebrengen, dat de laboratoria ten dienste van den landbouw overal van zelve ontstaan, waar de behoefte daaraan ontwaakt is; en dientengevolge zouden deze inrichtingen ongeveer in de volgreeks geconstateerd moeten worden, dat zij het eerst tot stand kwamen in de landen met een on twikkelden, rationeel gedreven landbouw, onafhankelijk van elkander, spontaan, ongeveer als bankinstellingen ontstaan op plaatsen, waar de finantieele ontwikkeling een zekere hoogte bereikt heeft. Hiernaar te werk gaande, zou men ten naaste bij verwachten moeten, dat het landbouwonderzoeks-wezen het eerst in Engeland krachtig het hoofd omhoog geheven hadde, vervolgens in Vlaanderen, Noordholland en eenige andere kustgebieden der Noordzee, dan eerst in Frankrijk en Midden Duitschland, en het laatst zeker van alle beschaafde landen in Oostenrijk en Italie.

Iets geheel anders leert de geschiedenis van deze ontwikkeling; en gelukkig is zij nog zoo nieuw, dat zij in alle details uit het geheugen van iederen man van 't vak zou kunnen ter neder geschreven worden. Het landbouw-onderzoekswezen, ofschoon in Engeland eenige weinig vruchtbare pogingen in deze richting gedaan werden, neemt zijn historisch uitgangspunt van eene geniale persoonlijkheid, Liebig, die ook hot eerst daarop opmerkzaam maakte, in welke graad chemie en andere natuurwetenschappen in den landbouw eene nuttige toepassing zouden kunnen vinden, on die daardoor eene verbazende gisting onder de belanghebbenden te weeg bracht. Dewijl nu Liebig een Duitscher was, en in zijn vaderland eenige mannen van beteekenis zich aan zijne zijde voegden, werd Duitschland de wieg van het landbouw-onderzoekswezen. Van dááruit geschiedt dan de verbreiding, niet volgens de zich openbarende behoefte, maar ongeveer als een besmettelijke stof op een bodem, die reeds sedert lang voorbereid is. En werkelijk, menig land bewees genoeg voorbereid te zijn, en wachtte slechts in stilte totdat de tijd van uitzaaien gekomen zoude zijn, en dit geschiedde overal door personen van bijzonderen aanleg, en niet rolgens vaste wetten.

Een Franschman met een zeldzaam onbevangen oordeel en in het bezit van een aanzienlijk vermogen ging, kort voor het jaar 1870, naar Duitschland, leerde de landbouw-proefstations kennen, werkte in een er van, en stichtte het eerste proefstation te Nancy, 
waarvan hij tegenwoordig nog bestuurder is, ja hij nam zelfs het initiatief, deze nuttige inrichtingen over geheel Frankrijk te verspreiden. Een zijner medewerkers werd eenige jaren later in het naburige België beroepen, en de vroegere assistenten van dezen zijn tegenwoordig de bestuurders van de zeer bloeiende Belgische Proefstations.

En in Nederland zelf. Ware de Inspecteur van het Middelbaar Onderwijs, die het ondernam, om do wet welke de oprichting van eene Landbouwsehool voorschreef, ten uitvoer te brengen, geen kenner van het Duitsche onderzoekswezen geweest, hij zoude niet aanberolen hebben, om aan de school tevens een Proefstation te verbinden.

Deze weinige punten zijn reeds voldoende, om ons van de meening terug te brengen, als ontstond het onderzoekswezen van zelve, overal daar, waar er behoefte aan bestaat; want dat deze behoefte reeds lang in België en Nederland bestond en zich niet eerst gelijktijdig met het tot stand komen van deze inrichtingen gevormd heeft, dit leert eenvoudig het buitengewoon toenemen van het aantal door het landbouwend publiek verlangde onderzoekingen aan een van deze Inrichtingen, wanneer het niet reeds uit zich zelve duidelijk ware, dat het landbouwbedrijt in een half dozijn jaren niet tot zulk eene evolutie in staat ware.

Te Wageningen b. v. zijn de inzendingen aan het Proefstation, van het jaar der vestiging, 1877 af, tot aan het jaar 1883, toegenomen van 380 op 1050; en Gembloux, het eerste Belgische Proefstation, toont, bij een wel is waar schroomachtig begin, een nog schitterender climax aan. Men kan het dus eenvoudig als een feit aannemen, dat ook in de jaren ' 77 in Nederland en ' 73 in België eene behoette van de zijde van het landbouwend publiek bestond naar de werkzaamheden, zooals zij door de Proefstations verricht worden; dat deze behoefte slechts voor het allerkleinste gedeelte door de reeds lang bestaande handelslaboratoriums berredigd konde worden, en dat deze behoefte toch niet de stichting van de noodige inrichtingen langs particulieren weg te weeg heeft kunnen brengen. De vraag had dus in dit geval niet, door het eenvoudig laisser faire, een voldoend aanbod ten gevolge gehad.

Het is gemakkelijk to begrijpen, waarom dit riet anders zijn kon, en het is misschien nuttig deze gronden bloot te leggen, omdat wij het daardoor meer en meer afleeren, om uitsluitend ééne theorie te volgen, die dikwijls slechts de ééne zijde der dingen kan verklaren, en daarentegen aanleeren de oogen open 
te houden voor den loop der zaken, zooals die werkelijk in deze bonte wereld is. De behoefte kan slechts dan met de noodzakelijkheid eener natuurwet een overeenkomstig aanbod te weeg brengen, wanneer de eerste aan belanghebbenden bekend en in een duidelijke, objectieve vraag uitgedrukt wordt. Verder zal het aanbod eerst dan de vraag op den voet kunnen volgen, wanneer tot het ontstaan van het bedoelde productievermogen niet meer tijd vereischt wordt, dan door menschelijk geduld en menschelijke speculatiegeest met gemak kan overwonnen worden.

Beide veronderstellingen zijn in ons geval niet van toepassing, want ten eerste is de behoefte naar onderzoekingen, zooals deze van de zijde der Proefstations geschieden, slechts onbewust voorhanden. Vele landbouwers weten b. v. alleen, dat de gemiddelde hoedanigheid van het zaaizaad, dat ter hunner beschikking staat, te wenschen overlaat, maar zij hebben er geen duidelijk begrip van, in welke mate een deskundig onderzoek naar de kiemkracht hierin licht zoude kunnen verschaffen. De sluimerende behoefte wordt echter door een bestaande Inrichting, die voor zulke onderzoekingen dient, wakker gemakkt, doordien met de gelegenheid tot onderzoek, ook de kennis van het aanmerkelijk voordeel dat langs dezen weg te bereiken is, zich in steeds ruimer kringen uitbreidt. En dan het aanbod. Zelfs aangenomen, dat deze kennis in sommige gevallen bij een bijzonder verlicht landbouwer, ten gevolge van bijzondere studiën in deze richting, aanwezig is, en dat deze zijne omgeving derwijze met dit idee weet in nemen, dat een bewuste en krachtige navraag in een aanmerkelijke mate te weeg wordt gebracht, komt dan deze vraag in onze maatschappij reeds met een aanbod van denzelfden aard overeen? Zit wellicht in een verborgen hoek iemand, die zich juist de bijzondere kennis en geschiktheid eigen gemaakt heeft, welke hem berekend doet zijn om de hem gedane opdrachten uit te voeren, en zal hij zich getroosten zonder werkzaamheid op deze problematische betrekking te wachten, totdat bij sommige landbouwers de bedoelde erkentenis begint door to schemeren?

Wij erkennen dus, dat aaubod en vraag elkander slechts dan op den roet kunnen, volgen, wanneer wij onbeperkte bewegelijkheid dezer beide factoren aannemen; zij zullen slechts dan het fondament kunnen worden van het optimistisch gebouw der "harmonie der belangen", wanneer zij zich plastisch naar elkander voegen. Doen zij dit niet van zelf, dan moeten zij met krachtige hand gevoegd worden, en daarmede komen wij tot eene belangrijke 
taak van den Staat, wanneer deze zich niet door abstrakte begrippen in zijne werkzaamheid laat beperken:

Het gebrek aan inschikkelijkheid, aan plastisch aaneensluiten van genoemde beide factoren der prijsbeweging is toch de oorzaak, dat ook elders de normale prijzen niet altijd worden gehandhaatd. Van daar de handelscrises, die treurige periodieke verschijnselen, die zulk een wanklank zijn in de voorgegevene harmonie der belangen. Daar vermindert ergens door eene omstandigheid van betrekkelijke toevalligheid, de vraag naar een belangrijk handelsartikel, maar het aanbod kan niet volgen, omdat de arbeidskrachten, die het bedoelde artikel produceerden, niet maar eenvoudig weg op een ander gebied kunnen worden aangewend, waarop de productie in hoogere mate loonend is. Men arbeidt nog een tijd lang dóór, zonder winst, in de hoop op verbetering, en verergert daardoor den toestand die eindelijk tot eene crisis leidt. Navraag naar arbeid is wel is waar ook hier voorhanden, maar naar een arbeid van eene andere soort, en dat is de oorzaak, dat de eene bepaalde soort van arbeid slecht beloond wordt, en dat zij die haar verrichten, honger lijden.

Hoe verder nu de verdeeling van arbeid gaat, en dus eene bepaalde soort van arbeid slechts onveranderlijk door eene bepaalde klasse van arbeiders verricht kan worden, des te grooter is het gevaar, dat handels- en industriecrises ontstaan. Op geen gebied is echter de arbeid minder geschikt, om van voorwerp te verwisselen, als op het gebied van geesteswerkzaamhoid. Het gaat moeilijk eenen boerenknecht er toe te brengen om wol te spinnen, maar bet is oneindig moeilijker, om een advokaat de kennis on kunstgrepen van een' praktiseh geneesheer eigen te maken, en wanneer die onmogelijkheid om arbeidskrachten des geestes in eene anderen vorm te gieten in maatschappelijke kringen minder tot verstoring leidt, ligt dit in de zeer gelijkmatige behoette der monschbeid aan de diensten van den geestelijke, den rechter, den geneesheer, den onderwijzer, daarnaast ook aan het grooter ekonomisch weerstandsvermogen van de hoogere klassen der maatschappij.

Maar men mag de hoop niet koesteren om arbeidskrachten des geestes van eene geheel bijzondere soort, voor iedere behoefte die zich mogelijkerwijze voordoet, steeds in voorraad te hebben. Niemand zal zich eene bijzondere vorming, om welke te verkrijgen licht een tijdsverloop van 10 jaron noodig is, eigen trachten te maken, wanneer hij niet na afloop van dezen langen voorbereidingstijd met 
eenige zekerheid rekenen mag, een loonend arbeidsveld te zullen vinden. Niemand, tenzij in buitengewone mate idealist.

Zoo komt het, dat eene massa van nuttig in elkander grijpende werkzaamheden, waaruit zelfs eene zeer aanzienlijke productie vau goederen volgen kan, achterwege blijft, wanneer alles aan het drijven van de neringdoenden volgens blinde natuurwetten overgelaten wordt; dat een stoot van buitenaf moet plaats hebben, om een nuttiger proces in werking to doen treden, dat dan later nog meer energie doet ontstaan dan er vonr aangewend is, en dat, eens geboren, zich zelf gemakkelijk onderhoudt. Deze stoot van buitenaf moet uitgaan van eene goede Regeering, bij wie men de aanwezigheid van intelligentie en geestkracht moet onderstellen, die een spanne verder ziet dan hare omgeving. Dezen stoot geeft feitelijk iedere Regeering; doordien zij het onderricht der jeugd loidt of als verplichting oplegt, uitgaande van de zekere overtuiging, dat ontwikkelde menschen door elkander gerekend productiever, zedelijker en gelukkiger zijn dan niet-onderrichten. Dezen stoot geeft de Staat op dezelfde wijze, wanneer hij voor de vorming en benoeming van rechters zorgt, en het niet aan het particulier initiatief overlaat, of aanzienlijke en scherpzinnige mannen bereid zullen gevonden worden, om aan de behoefte aan "uitspraak in geschillen" te voldoen, en genegen zijn om tegen betaling oneenigheden te beslechten. (Ik kies dat schijnbaar ver afliggend roorbeeld met voordacht, omdat ook het ambt van Directeur van een Proefstation medebrengt, in zekeren zin rechter te zijn in geschillen).

Diezelfde stoot, of aansporing, geeft de Staat echter ook, en vaker dan men denkt, op het gebied der industrie en niet alleen door het onderhoud van vakscholen, die voor bepaalde onderdeelen der industrie voorbereiden. Hij geeft die b. v. wanneer hij belastingen voor nieuwe gebouwen of pas ontgonnen gronden vermindert, wanneer hij aan een nieuw ontstane industrie een voorbijgaand beschermend recht toestaat, hij geeft die, wanneer hij de krijgsvloot aan het opsporen van nieuwe zeewegen doet deelnemen, bij de oprichting van meteorologische instellingen, en in vele andere gevallen.

Nu kan men zich wel is waar op het standpunt stellen, dat de Staut niet zonder dringende noodzakelijkheid in de private werkzaamheid der menschen behoort in te grijpen. Maar het getuigt van inconsekwentie en gedachteloosheid, te verlangen dat hij dit in het geheel niet moet doen. Met andere woor- 
den, het is hier, bij de uiteenloopende meeningen der partijen slechts om een $\mathrm{kwantitatief,} \mathrm{niet} \mathrm{om} \mathrm{een} \mathrm{kwalitatief} \mathrm{onder-}$ scheid te doen. Overal, ook in Engeland en Noord-Amerika, de klassieke landen van het "help yourself", doet de Staat meer dan het bezorgen van rechtszekerheid en het verdedigen der grenzen van het land en die enkele dingen meer, waartoe hij zich volgens de zuivere leer van het laisser-faire te beperken had. Slechts zooveel is juist, dat de grenzen van den staatszorg in verschillende tijden en in verschillende landen zeer uiteenloopend plogen gesteld te worden, on wel derwijze, dat bevolkingen met veel-zelfvertrouwen, energie on volharding, de bemoeiingen van den Staat, als dikwijls nutteloos, zoeken te hesnoeien, terwijl men in andere landen, waar aan de bevolking de genoemde eigenschappen ontbreken, die nergens meent te kunnen ontberen.

Terwijl nu in deze dingen een zuiver principieel onderscheid niet aan te toonen is, moeten or wel overwegingen van meer bijzonderen aard bestaan, die slechts met betrekking tot de vraag, of bepaalde instellingen staatsinstellingen moeten zijn of niet, opheldering verschaffen, en wel zal het beslissend zijn of eene ontwijfelbaar nuttige zaak, niettegenstaande het nut er van in naburige landen en in het land zelf erkend wordt, toch niet als particuliere onderneming tot stand komt. In dit geval zal de Staat de behulpzame hand moeten bieden, hoe ook de meeningen in toongevende kringen omtrent de nadeelen der overdreven staatsbemoeiing en omtrent de voordeelen van het private initiatief mogen zijn.

Deze overwegingen van meer bijzondere natuur aangaande de landbouw-proefstations, zijn nu reeds grootendeels te vinden in hetgeen in de inleiding van dit opstel gezegd werd omtrent den historischen gang van de ontwikkeling der Proetstations. Wij hebben daar gezien, dat de verspreiding dezer instellingen niet paralel gaat met de algemeene landhuishoudkundige ontwikkeling van een land, hetgeen toch het geval zoude moeten zijn, wanneer zij als winstgevende particuliere ondernemingen overal daar te voorschijn kwamen, waar de toestand er rijp voor geworden is; dat zij veel meer van een bepaald aanwijsbaar middelpunt uit, zich verspreid hebben, even als eene besmettelijke ziekte, of om een schooner beeld te gebruiken, even als de zaaier zijn zaad uitstrooit. De mannen, die daarbij de rol van zaaier vervuld hebben, zijn met name te. noemen. 
Dat echter de Proefstations geen kunstplanten zijn, misschien uit een philantropischen luim des Staats onderhouden, en die juist daarom niet van zelve ontstaan, omdat zij op onzen bodem niet kunnen tieren, dat wordt het best bewezen uit de groote sympathie, waarmede zich deze instellingen in kringen van boeren mugen verheugen; dat wordt duidelijk, zelfs voor hem die bewijs van geldelijk voordeel verlangt eer hij het nut eener zaak erkent, uit het feit, dat vele contrôle-stations, nadat zij tot volle ontwikkeling gekomen zijn, financieel zich zelve onderhouden. Men beproeve het eens, om het Proefstation to Wageningen, dat toch betrekkelijk nog eene jonge inrichting is, op te heffen of te sluiten, en men zou in vele kringen een' storm zien opkomen, die zich door petitie op petitio zou openbaren.

Echter niet alleen wegens de opgegeven gronden, dat nl. Proefstations, ook daar waar ongetwijfeld behoefte aan deze instellingen bestaat, niet of zeer laat geboren worden, tenzij de Staat bij de geboorte eenige hulp verleent, is het aan te bevelen, dat deze de grondvesting er vau tot zich trekke. Er kunnen nog geheel andere en niet minder gewichtige gronden voor dit initiatief te berde gebracht worden. Ik bedoel de onafhankelijkheid van staatsbeambten tegenover de belangen van het koopend en vorkoopend publiek.

Om goed duidelijk te maken wat ik bedoel, en om misschien niet in verdenking te komen om ondernemers van private laboratoria van grove omkoopbaarheid te beschuldigen, grijp ik eenige gevallen uit de praxis der handelslaboratoria, waardoor in dit geval meer zal worden bewezen dan door lange theoretische beschouwingen.

Verkoop van suiker tusschen fabriekanten, raffinadeurs en handelaars vindt natuurlijk plaats naar het gehalte van de ruwe koopwaar aan werkelijk zuivere suiker, en overal waar suikerindustrie en suikerhandel eenige beteekeuis verkregen heeft, ontstaan laboratoria, waar het gehalte aan zuivere suiker vastgesteld wordt. Dit geschiedt in dat geval in toereikende mate door het initiatief van particulieren, daar kooper zoowel als verkooper de noodzakelijkheid van zulk eene handelwijze duidelijk genoeg begrijpen en niet schromen eenige kosten aan te wenden, ten einde zich eene objectieve beoordeeling te verzekeren. Ofschoon nu eene suikerbepaling tot die operaties behoort, waarbij met uitmuntende optische werktuigen een zeer hooge graad van volkomenheid verkregen is, verhindert dat toch niet, dat men door kleine wijzigingen in de be- 
werking, hetzij met betrekking op de wijze, waarop het monster genomen wordt of op de hoeveelheid der bijgevoegde lood-suiker, en waarvan een ieder ongeveer dezelfde rechtvaardiging roor zich in beslag nemen kan, eenige tiende gedeelten van een procent suiker meer of minder in dezelfde soort vinden kan. Het nog overblijvende verschi! zoude allen invloed op handel en wandel verliezen, wanneer de suikerscheikundigen zich vereenigden tot het aannemen van een nauwkeurig omschreven handelwijze, ook wanneer deze op zich zelf geenszins als de alleen gerechtvaardigde beschouwd kan worden. Wat gebeurt echter?

Wanneer ik mijn zegsman, die zelf zulk een suikerscheikundige is, en de ellende van den tegenwoordigen toestand in eigen persoon ondervonden beeft, geloof mag schenken, zoo kiest een fabriekant dio verkoopen wil, uit voorliefde niet dien scheikundige uit, die volgens zijne (des fabriekanten) eigene overtuiging de beste uitkomsten verkrijgt, maar lem die de hoogste analyse-rapporten afgeeft. $\mathrm{Er}$ is hiervoor een eigene technische uitdrukking ontstaan, en men spreekt in den handel van scheikundigen die "hoog analyseeren" of die "laag analyseeren", zonder dat daarbij, zooals ik op nieuw wil te kennen geven, van een opzettelijke vervalsehing der uitkomsten sprake is. Mijn zegsman nu beweert de aanzienlijke klandisie van eene fabriek verloren te hebben, omdat hij (mijn zegsman) minder hoog analyseerde dan een ander scheikundige, tot wien de fabriekant overging, eenig on alleen op dien grond, terwijl te gelijkertijd de vertegenwoordiger der bedoelde fabriek mondeling als zijne overtuiging mededeelde, dat hij nauwkeuriger analyseerde dan de andere, dat echter de concurrentie hem dwong, om alle voordoelen zich toe te eigenen, die zich aan zijne onderneming voordeden, en wat in dergelijke gevallen meer te berde gebracht wordt.

Wij zien hier eene omstandigheid, bij het groote publiek minder bekend, maar juist daarom eischend, dat men haar met den ringer aanwijze. Een handels-scheikundige, die van de opbrengst zijns arbeids leven moet, wordt hij niet door zulke gebeurtenissen moreel (of liever immoreel) gedwongen, om methodes te laten varen, die toch volgens zijne overtuiging de beste zijn?

Nu zorgt in den suikerhandel de kooper, die toch ook kenner is en zijn deskundige ter hand heeft, er voor, dat de boomen niet in den hemel groeien; hij laat zich niet iedere analyse zó́ maar welgevallen, en zoo komt het, dat deze verkeerde toestanden nooit 
aanmerkelijke uitbreiding kunnen verkrijgen, en juist daarom heeft zich nog nergens de behoefte geopenbaard, de hier bedoelde suikerlaboratoria tot staatsinstellingen te maken. - Anders is het in den handel met grondstoffen ten dienste van den landbouw. Hier staat de geslepene handelaar tegenover een' op het gebied der analyse volkomen onervaren en eenvoudigen landbouwer, die zijn eigen voordeel niet kent, en de invloed van deze verhouding is duidelijk genoeg waar te nemen in de landen, waar de landbouwproefstations geen staatsinstellingen zijn, maar als eenvoudige handelslaboratoria of als stations door landbouwvereenigingen onderhouden, bestaan, zooals b. v. in Engeland en vroeger in Frankrijk. Daar vinden of vonden wij ook overdrevene begunstigingen aan handelaars en fabriekanten van kunstmeststoffen en voedermiddelen in de gedaante van "hooge analysen." In Engeland b. v. worden de Superphosphaten bij het onderzoek naar oplosbaar phosphorzuur met heet water uitgeloogd, waardoor men tot een procent meer verkrijgt. De methode heett, voor zooverre men zien kan, geen recht van bestaan, omdat toch in den bodem geen heet water tot oplossing van het phosphorzuur ter beschikking staat, en zij is de bron van talrijke verdrietelijkheden bij het onderzoek van produkten die uit Engeland overkomen. Maar haar ontstaan is te verklaren uit eene begunstiging der zeer machtige meststoffabriekanten, van de zijde der handelsscheikundigen, en de eersten vergoeden deze hulpvaardigheid met ongekend hoog honorarium voor de analyses. Ook hier is geen sprake van omkooping of onzedelijkheid, maar slechts van een nadeelige toegeefelijkheid, door het aannemen van eene methode, waarvoor hier of daar ook eene theoretische verdediging te vinden moge zijn, die zich echter in volkomen neutrale instellingen niet zoude kunnen staande houden.

Uit volkomen dezelfde oorzaak is het te verklaren, dat op de Engelsche analyse-bulletins niet phosphorzuur berekend wordt maar phosphaat, niet kali maar akalien. Dat heeft den schijn van iets meer, en is daarom in het belang van den handelaar. Yets dergelijks was vroeger in Frankrijk ook aan de orde van den dag.

Mon begrijpt, dat al deze kleine ongerechtigheden en partijdigheden van het onderzoek verdwijnen, wanneer dit geschiedt in staatsinstellingen, waar staatsbeambten met een rast inkomen aangesteld zijn, welke laatste niet to vragen hebben naar de schoone oogen van deze of gene kunstmest-Croesus. Vergissingen zijn natuurlijk in staatsinstellingen even goed mogelijk als in 
private instellingen, maar er bestaat in gene geenerlei oorzaak, dat de dwalingen zich in ééne richting zullen bewegen. Men zegge ook niet, dat het eene ongerechtraardigde begunstiging van den boerenstand zij, dat men door de oprichting van rijksproefstations, die uitsluitend ton dienste van zijn beroep werkzaam zijn, hem tegenover orerwinsten van den handel waarborgt, terwijl de andere bedrijven hiertoe grootendeels op eigen initiatief blijven aangewezen. De boerenstand onderscheidt zich toch in enkele punten anmerkelijk van alle andere neringdrijvende standen. Niet alleen dat deze stand de groote wieg der bevolking is, waaruit zich de hoogere standen, die toch voortdurend uitsterven, regelmatig aanvullen, - en reeds uit dit gezichtspunt den nadenkenden volkshuishoudkundigen gewichtig moet voorkomen - maar voornamelijk het feit van de veelzijdigheid van het landbouwberoep, waardoor het aan het individu bezwaarlijk valt, om aan al do eigenschappen te voldoen, die een waar landbouwer moet bezitten, moet hier in het verdiende licht gesteld worden.

Wij streven tegenwoordig naar een hoogere intellectueele ontwikkeling van den boerenstand, die voorzeker bij andere standen achtergebleven is, en ongetwijfeld mag eene meer rationeele händeling in zijn bedrijf als vrucht hiervan verwacht worden, Maar mon vergeet al te dikwijls, dat het den bewoner van het platteland moeilijker vallen moet, om zich deze ontwikkeling eigen te maken, dan den jongen handwerksman of industrieel, dewijl hij, om dit met goed gevolg te doen, voor eenigen tijd zich naar de kringen der beschaving moet verplaatsen, alwaar hij soms meer goede boerengewoonten afwent, dan hij aan theoretische vorming wint. Dit en niets anders is dan ook de door weinigen opgemerkte, moeilijk te vermijden klip, waarop zoo vele landbouwscholen schipbreuk geleden hebben.

De landbouwer moet naast de kennis van veel feiten zeer bepaald gekenmerkte karakter-eigenschappen bezitten, om een goed landbouwer te zijn, on eene zekere strengheid tegenover zich zelven staat daarbij op den voorgrond, een strengheid tegenover zich zelven, die door den verweekelijkten fabriekarbeider zoo zeer ontzien wordt, dat hij, lot armoede vervallen, niet licht tot het besluit komt, weder tot den boerenstand terug te keeren. In die mate hebben deze karakter-eigenschappen een beslissenden invloed op het vooruitkomen van den landbouwer, dat wij veel eerder een niet-ontwikkelden boer ontmoeten, die toch rijk 
geworden is, dan een slaapmuts wien dit gelukt is, moge zij ook een door onderricht goed ontwikkeld hoofd bedekken. De weinig vleiende epitheta, die spotachtige stedelingen de boeren gelieven toe te voegen, zijn hicrvoor de beste vingeraanwijzing.

Wij maken hieruit de gevolgtrekking, dat men ran de intellectueele ontwikkeling der landbouwers, hoeveel men die ook bevorderen moge, niet te veel verlangen mag. Wij mogen ons niet terug laten brengen van de overtuiging, dat de ontwikkeling van geheel hun wezen in eene andere richting, slechts eene matige in de genoemde richting laat verwachten, zoodat eenige tegemoetkoming van den Staat, om hem bij den aankoop van zijno grondstoffen niet alleen maar aan het spel der vier winden prijs te geven, maar hem hiertoe een' vertrou wbaren raadgever ter zijde te stellen (die bovendien aan den Staat zoo weinig kost) hier geheel en al ter plaatse schijnt te zijn. Want wanncer men ook al hiertoe niet wil overgaan, ten einde den boer te dwingen zich zelven te helpen, zooals handel en industrie zich zelven plegen te helpen, in rertrouwen op de stelling, dat juist hij, die uit het ekonomisch standpunt het sterkst is, den zege behale en de zwakke op zij gedrongen worde, is er toch geen vooruitzicht, dat de werkelijkheid met deze stelling overeenkomen zal. De aankoop van grondstoffen in den Landbouw is toch slechts een der vele momenten, waarvan een goede landbouw athankelijk is, zoodat deze factor tegenover concurreerenden bijna nooit beslissen zal. Het eindresultaat wordt bijna steeds te weeg gebracht door arbeidzaamheid, zoodat bijna bij iedere onderneming, (zeer in strijd met bekende versehijnsels in de Industrie,) de heereboer voor den zelf medearbeidenden boer het zeil moet strijken. Doet de Staat niets, dan blijft de zaak eenvoudig achterwege, on door dat achterwegeblijven wordt de landbouw van een land voor honderdduizenden, ja voor millioenen benadeeld.

Ten slotte kan nog voor de instelling der Landbouwproefstations van Staatswege te berde gebracht worden het groote voordeel van eene rationeele organisatie van verschillende inrichtingen voor onderzoek in een en hetzeltde land, eene organisatie, die ook nooit door het blinde werken der ekonomische krachten tot stand zal komen. Men kan aau de inrichtingen voor onderzoek werkzaamheden opdragen, waarmede zij zich in den tijd die niet door contrôlearbeid in beslag genomen wordt, bezig kunnen houden; werkzaamheden die in het bijzonder betrekking hebben op de landstreek, waar zij zich bevinden. Men kan hen in de veen- 
koloniën het doen van bemestings- en grondverbeterings-onderzoekingen opdragen; in weidestreken de verbetering van het onderzoek van graszaden, in de nabijheid der zee onderzoekingen over het gebruik als meststof van den afval der vischvangst enz. Meer dan deze aanduiding te geven schijnt hier overbodig te zijn.

Wageningen. $\quad$ A. MAYBR. 